\title{
The socio-economic consequences of the desertification processes in Mongolia.
}

\author{
Darima Darbalaeva ${ }^{1, *}$, Anna Mikheeva ${ }^{1}$, and Yulia Zhamyanova $^{1}$ \\ ${ }^{1}$ Baikal Institute of Nature Management SB RAS, Laboratory of Nature Management Economics, \\ 670047, 8, Sakhyanova str., Ulan-Ude, Russian Federation
}

\begin{abstract}
The comparative assessment of the aimags population living standard and the country average level was carried out and some problem areas requiring closer examination were identified. We evaluated 12 indicators characterizing the development of the economic and social sphere of aimags, using the method of ranking calculated indices based on 2010 and 2018. The economy transition to a market entailed significant changes in the life of pastoralists. The desertification processes strongly influence the living standard of the herders whose level of prosperity is rather low compared to the country average level.
\end{abstract}

\section{Introduction}

Desertification and land degradation have vast interconnected causes and consequences in all three dimensions of sustainable development. It is estimated that $40 \%$ of the world's degraded land is in area of high poverty, approximately 1.5 billion people worldwide with their livelihood depending directly on this degraded land. Mongolia has 77 percent of territory and almost 90 percent of its pastureland is under threat of desertification and land degradation [1].

Mongolia's main economic sectors are agriculture, coal, gold and copper mining industries. The agricultural sector in Mongolia makes up a large share in the country's economy (over 20 percent of GDP). Compared to 1990, the number of livestock has been increasing sharply and thus the pasture carrying capacity has exceeded its normal capacity. Desertification can be said to have increased due to overgrazing and soil degradation. The mining industry is also one of Mongolia's most important industries. The country's richest resources are minerals: coal, copper, fluorite, gold, iron ore, lead, molybdenum, oil, phosphates, tin, uranium, and wolfram. In the last few years, gold mining has contributed to severe land damage. Hence in Mongolia, the natures of its flourishing economic sectors are related closely to land degradation, and in turn soil degradation has become one of the biggest challenging environmental issues [2]. According to the definition of desertification, $40 \%$ of the Mongolia's territory is covered with desert [3]. An assessment of desertification and land degradation in Mongolia, made by Mongolian researchers in 2015, showed that $76.9 \%$ of the total area was under desertification and land degradation processes [4]. The degradation of pastureland has occurred rapidly as a consequence of

*Corresponding author: darbalaeva@binm.ru 
herding controls being replaced by open access during the transition from socialism to a market economy. Therefore, range carrying capacity status which includes available herb biomass and predicted livestock consumption. In recent years, land degradation, as measured by the decline of soil fertility and desertification as grasslands decrease, has increased with more grassland becoming sandy. [5]

After 1990 Mongolia has emerged into a world that challenges its longstanding approaches to pastoralism as the state retreats from active participation and market economics becomes a driving force. From a broad perspective environmental changes are affected by mobility, water supply, variable rangeland quality, land tenure, livestock preferences, and herder motivations. At the local level pastoralists remain in need of water and adequate grazing land for livestock, and the skills to cope with natural variablesprecipitation, dzuds, drought, and heat; naturally occurring events - insect invasions, wind, dust storms, saline water; and human agency-movement patterns, intensified grazing, constructed water sources, motorized transport, emergency fodder, mining, and financial decisions. The sustainability of pastoralism remains uncertain with new government regulations, climate change, economic forces, and natural conditions impacting herding. [6]

This paper aims to contribute to the broader literature on social and ecological issues in Mongolian herders livelihood by estimating some socio-economical indicators from official statistical data.

\section{Study area population characteristics}

The consequences of desertification processes affect not only aimags, where these processes take place directly, but also indirectly affect the life of all territories of the country.

The transformation of demographic system of Mongolia took place from the beginning of the reforms in the 90 s of last century, and associated with the growth of the urban population, population migration, etc. The total population of Mongolia at present time is 3238 thous. persons (2018 data) and characteristically is too much dispersed, which is due to nomadic farming method. There is still a low population density, the period of almost 30 years shows only 1.6 times growth from 1.3 person per sq. $\mathrm{km}$ in 1989 till 2.1 in 2018. [7]

The relief and climate contrasts as well as the various levels of water supply of the territory determine the unbalanced population distribution. The highest population density is in the river valleys of the forest-steppe zone, the lowest - in desert areas as well as in mountainous areas. The most densely populated northern part of the country, where are the main industrial centers (Ulaanbaatar, Darkhan, Erdenet), and also concentrated along the railways Ulaanbaatar - Sukhbaatar, Ulaanbaatar - Erdenet, Ulaanbaatar - Choir, and highways Ulaanbaatar - Arvaikheer, Tsetserleg - Kharkhorin and Ulaanbaatar - Baganuur. The main attractive forces are well-developed industrial and social infrastructure, possibility of sale of agricultural products. [8]

The density of the reviewed aimags did not change significantly from 1989 to 2018, except aimag Orkhon where it almost doubled (Table 1). Mostly the density increased, but in Dundgovi aimag it has decreased and the main factors of this presence we will consider further.

The collection of study areas can be divided into two parts: northern aimags with population amount about 100 thous. persons and southern aimags with population about 50 thous. persons but only northern Bulgan aimag has low population level (fig. 1). The depression points until 2010 shows the crisis caused by dzuds - natural disasters negatively affected on herders' life and destroyed a huge number of livestock and directed a lot of people to the cities looking for a job and ways to survive. 
Table 1. Population density change since 1989-2018, person/sq.km

\begin{tabular}{|l|r|r|r|r|r|r|}
\hline & $\mathbf{1 9 8 9}$ & $\mathbf{2 0 0 0}$ & $\mathbf{2 0 0 5}$ & $\mathbf{2 0 1 0}$ & $\mathbf{2 0 1 5}$ & $\mathbf{2 0 1 8}$ \\
\hline Mongolia & 1.3 & 1.5 & 1.6 & 1.8 & 2.0 & 2.1 \\
\hline Selenge & 2.1 & 2.4 & 2.3 & 2.4 & 2.6 & 2.7 \\
\hline Darkhan-Uul & 26.0 & 25.8 & 27.1 & 28.8 & 30.6 & 32.1 \\
\hline Bulgan & 1.1 & 1.3 & 1.1 & 1.1 & 1.2 & 1.3 \\
\hline Orkhon & 70.2 & 95.6 & 102.3 & 113.7 & 125.9 & 132.5 \\
\hline Khuvsgul & 1.0 & 1.2 & 1.2 & 1.1 & 1.3 & 1.3 \\
\hline Dundgovi & 0.7 & 0.7 & 0.6 & 0.5 & 0.6 & 0.6 \\
\hline Umnugovi & 0.3 & 0.3 & 0.3 & 0.4 & 0.4 & 0.4 \\
\hline Dornogovi & 0.5 & 0.5 & 0.5 & 0.5 & 0.6 & 0.6 \\
\hline Bayan-Ulgii & 2.0 & 2.0 & 2.0 & 1.9 & 2.2 & 2.3 \\
\hline
\end{tabular}

Over these years, almost all aimags lost its population, but urban areas has been growing (Ulaanbaatar, Darkhan and Orkhon). Along with that Umnugovi and Dornogovi became the centers of attraction due to active development of mining industry. But anyway almost all aimags have positive dynamics except Dundgovi, it lost $23.5 \%$ of total population from 2000 till 2010 and did not recovered yet (fig. 1). There is a general tendency in dynamics of natural growth to slow down, but the level still remains high.

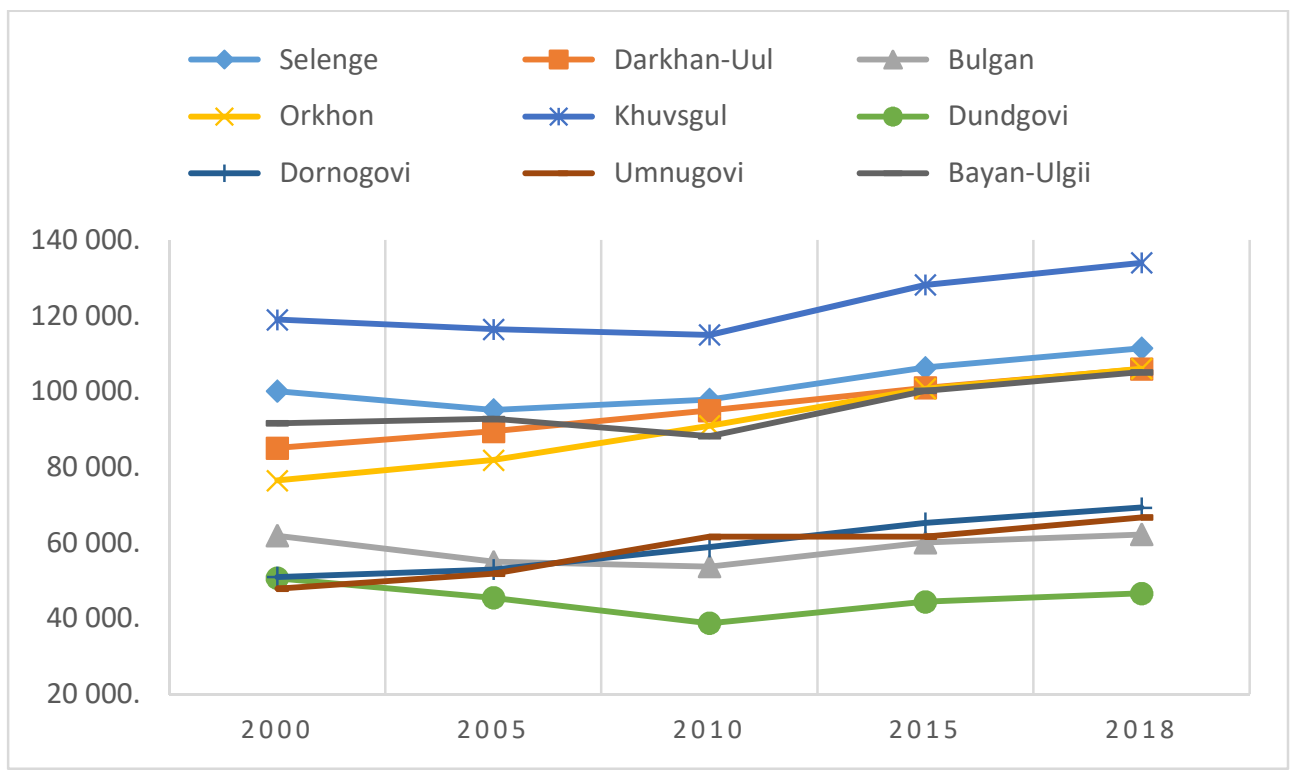

Fig. 1. Population dynamics.

\section{Data analysis}

We evaluated 12 indicators characterizing the development of the economic and social sphere of aimags, using the method of ranking calculated indices based on 2010 and 2018 data and we have to conclude that there is no statistical data about population income at aimags level and a great shortage of other data concerning our research field. At [9] we used another set of indicators such as internet, cellular phones, electricity, engineering 
systems indices. Unfortunately, such essential indicators as proportion of population without access to safe drinking water sources, proportion of population living in houses and apartments with connections to engineering service networks and others occurred in list of official statistical data just once in 2010.

First group of indices concerns of HDI (human development index) and its components (education index, life expectancy index and GNI index per capita by PPP). At fig. 2 we can see that blue line of HDI seems the same after 8 years, but its dimension indices lines are significantly another. Actually there is a little decrease in HDI level in all aimags and country in whole. We have to mark that there is a GDP per capita in 2010 and GNI per capita in 2018 (methodology changed after 2010 in 2011, GNI per capita started to be used), but the difference between two indicators is insignificant and we can state the considerable increase of indicator. The reverse situation with education index - its level decreased from 0.928 in 2010 till 0.720 in 2018 in Mongolia average and that was after methodology change too. Only life expectancy index didn't change significantly.

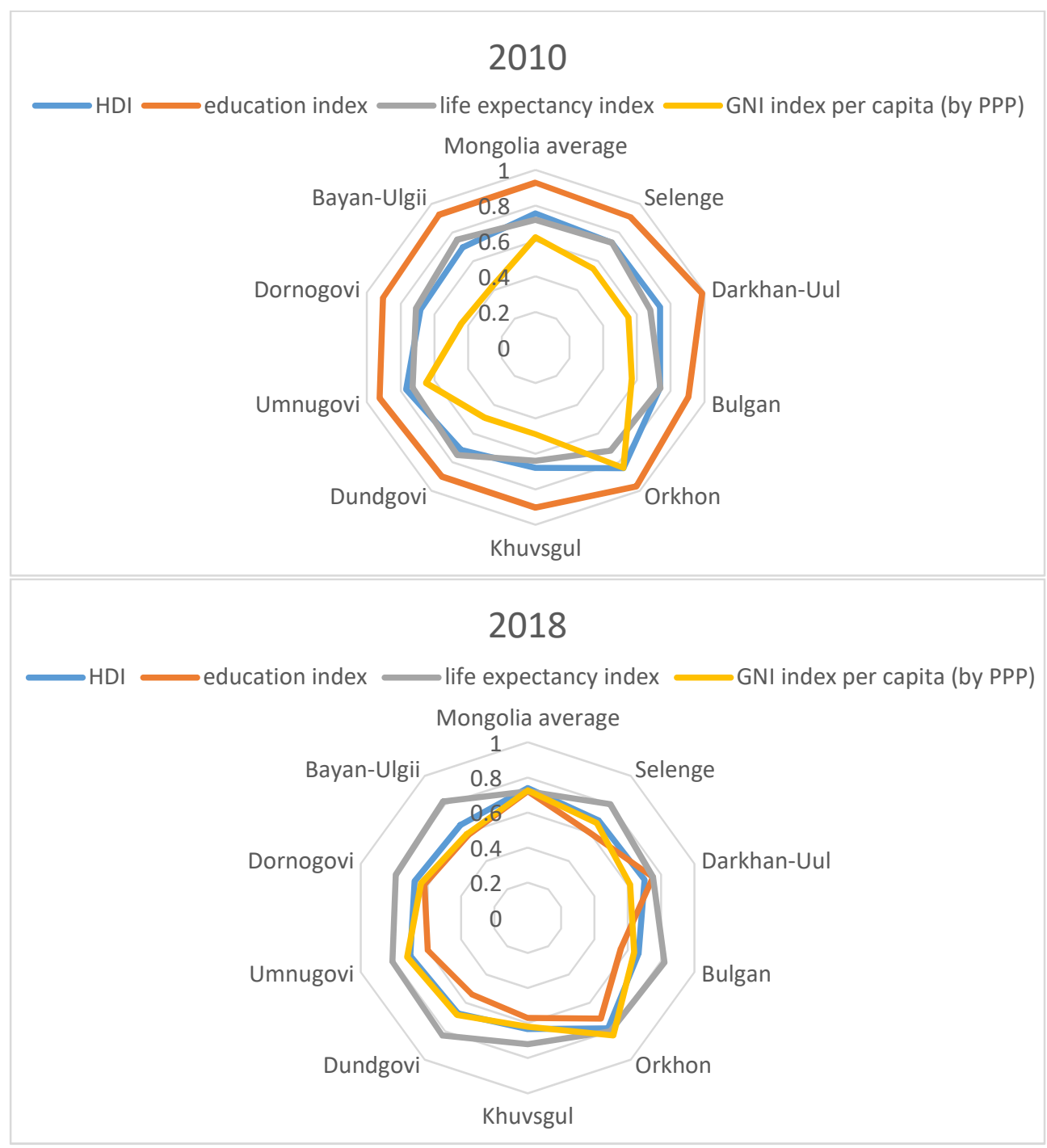

Fig. 2. HDI and its dimension indices. 
As for situation among aimags - HDI of aimags Orkhon and Umnugovi were higher than country average in 2010 and only Orkhon in 2018, education index in Darkhan-Uul, Orkhon were above average in 2010 and only Darkhan-Uul in 2018, Orkhon became below average by 0.01 points and still higher than other aimags. The country average life expectancy index remained at the same level but aimags' index increased by $0.07-0.08$ points and became higher than country average. The level of GNI index per capita increased significantly but the distribution among aimags stayed the same, highest in Orkhon and Umnugovi.

The crime index is based on the recorded crime rate per 10000 population aged 16 and above and overall situation changed for the better, if earlier Selenge and Dornogovi aimags were above country average than later all studied aimags are down average (fig. 3).

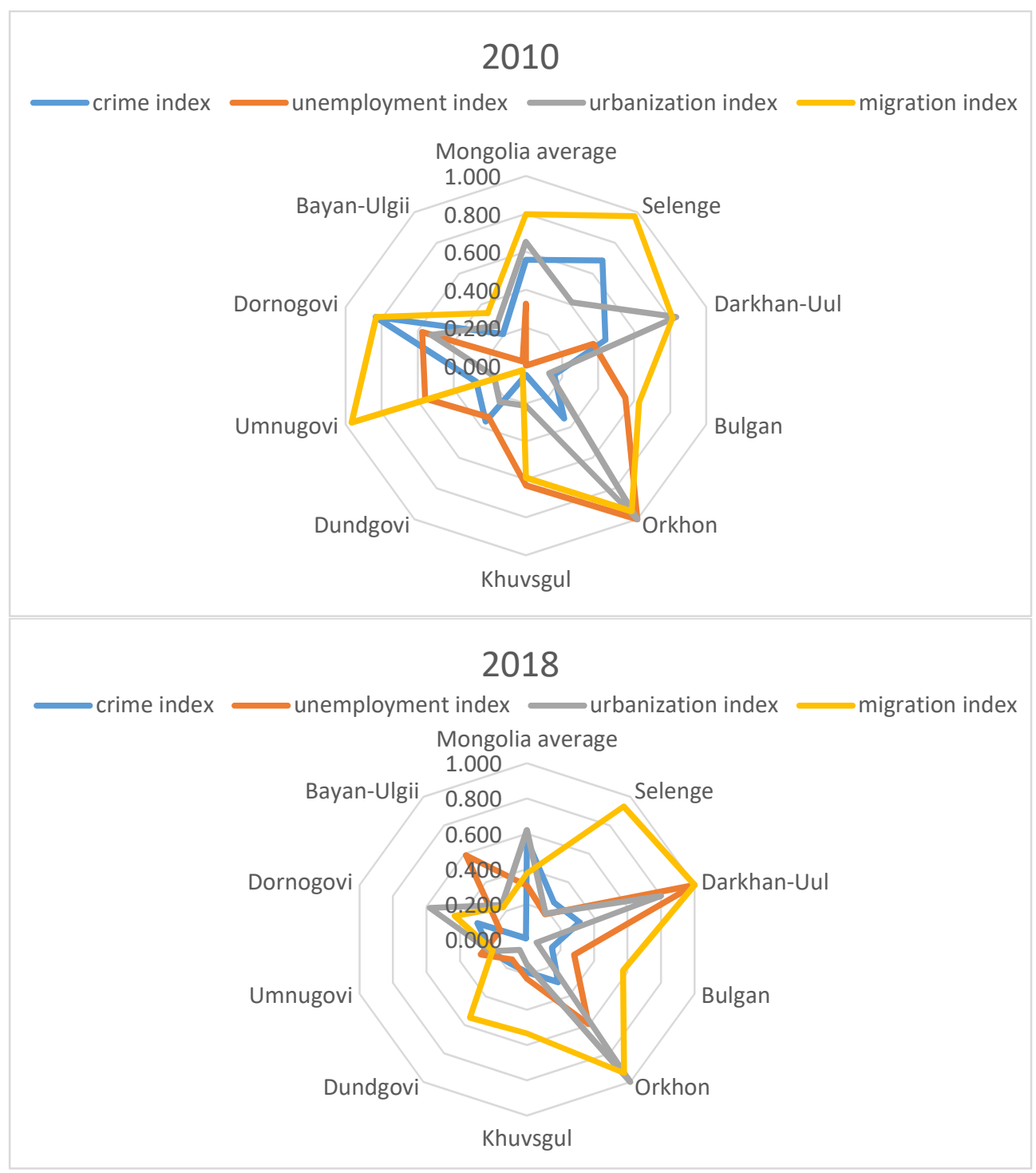

Fig. 3. Crime, unemployment, urbanization and migration indices. 
The registered unemployment situation changed in following way - maximum has shifted from Orkhon to Darkhan-Uul, and if earlier 7 of 9 aimags were above average country level $9.9 \%$, later only three aimags Darkhan-Uul, Orkhon and Bayan-Ulgii were higher than average $7.8 \%$.

Population growth and shifts in its distribution are accompanied by a change in urban and rural population ratio, the urban population increased from $55.3 \%$ (1990) to $67.9 \%$ (2018), mainly due to Ulaanbaatar city growth, its share in all country population grew from $27.2 \%$ (1990) to $46.1 \%$ (2018). The urbanization index shows the distribution by proportion of urban population. There are two urban areas with small territory Orkhon and Darkhan-Uul, in other aimags there is a trend of urban share decrease. The share of urban population in Orkhon aimag with one of the largest cities of Mongolia Erdenet is more than $96 \%$, in Darkhan-Uul aimag with city Darkhan - $81 \%$.

Migration is one of the most important factors affecting resettlement. During last almost 30 years migration processes aimed at moving population to the central part of Mongolia, mainly to the cities Ulaanbaatar, Darkhan and Erdenet. The migration index reflects the situation with high peak of internal migration in 2010 and subsequent decline in 2018. In 2010 the attraction centers were cities, northern aimags and southern aimags with developing mining industry as we said before, this way we can say that population distribution depends on large scale of internal migration in a greater degree than a natural movement of population. But by this moment Darkhan-Uul, Selenge and Orkhon are still attractive enough for migrants.

Internal migration processes took shape of population moves to large cities and regional centers, including herders, trying to be closer to the points of sale of their livestock products. Intensive urbanization began after the new constitution adoption in 1992, which states that every citizen of Mongolia has the right to choose a place to live. Ger areas have grown in large cities such as Ulaanbaatar, Darkhan and Erdenet, especially after 1999-2002 natural disasters dzud and drought. It led to the expansion of these cities, as well as the degradation of urban and suburban lands. The state of urban ecosystems in Ulaanbaatar has become worse since the transition to a market economy. Now in Ulaanbaatar there are fewer trees and green parks, although the population has almost doubled with the transition to the market. The level of soil, water and air pollution in the capital became worse with an increase of ger areas [10]. And if consider to a longer period 1990-2018 the population of Ulaanbaatar increased almost three times and concentrated $46.1 \%$ of country total population. More and more herders graze their livestock all the year at suburban areas with aim not to miss the market opportunities, and the distances of nomadic migrations significantly reduced, what negatively affects the surrounding large settlements pastures. The results of our sociological polls in Orkhon soum of Darkhan-Uul aimag showed that many livestock breeders prefer to increase the number of cattle in their herd, since they believe that it is more profitable for them in the conditions of a transition to a sedentary lifestyle. Many of them began to build permanent houses instead of traditional gers. Thus, overgrazing in suburban and infrastructural territories increased. Saintsagaan soum of Dundgovi aimag, where Mandalgovi aimag center situated, is illustrative in this regard. In 1996, there was a sharp increase of soum's population share in total population of aimag, which indicated a concentration process of the population around a large settlement - aimag center. In general, we can conclude that by now Dundgovi aimag has almost exhausted most of its natural resources for ecosystem goods producing, what already affected agriculture. Other aimags are in danger of coming to the same condition as long as further intensive exploitation of nature by irrational farming methods.

The main reasons for migration are access to developed socio-economic infrastructure and the possibility of agricultural products sale. The population migration and resettlement from territories under desertification processes, especially from the nearby Govi aimags, 
intensified significantly about $10-15$ years ago. At the same time, there was a great increase in pasture load in connection with the resettlement of herders to the northern aimags.

Infant mortality as well as life expectancy characterize the overall situation in public health service and availability of medical services and it is typical that high means of index are at slightly urbanized territories. (fig. 4)

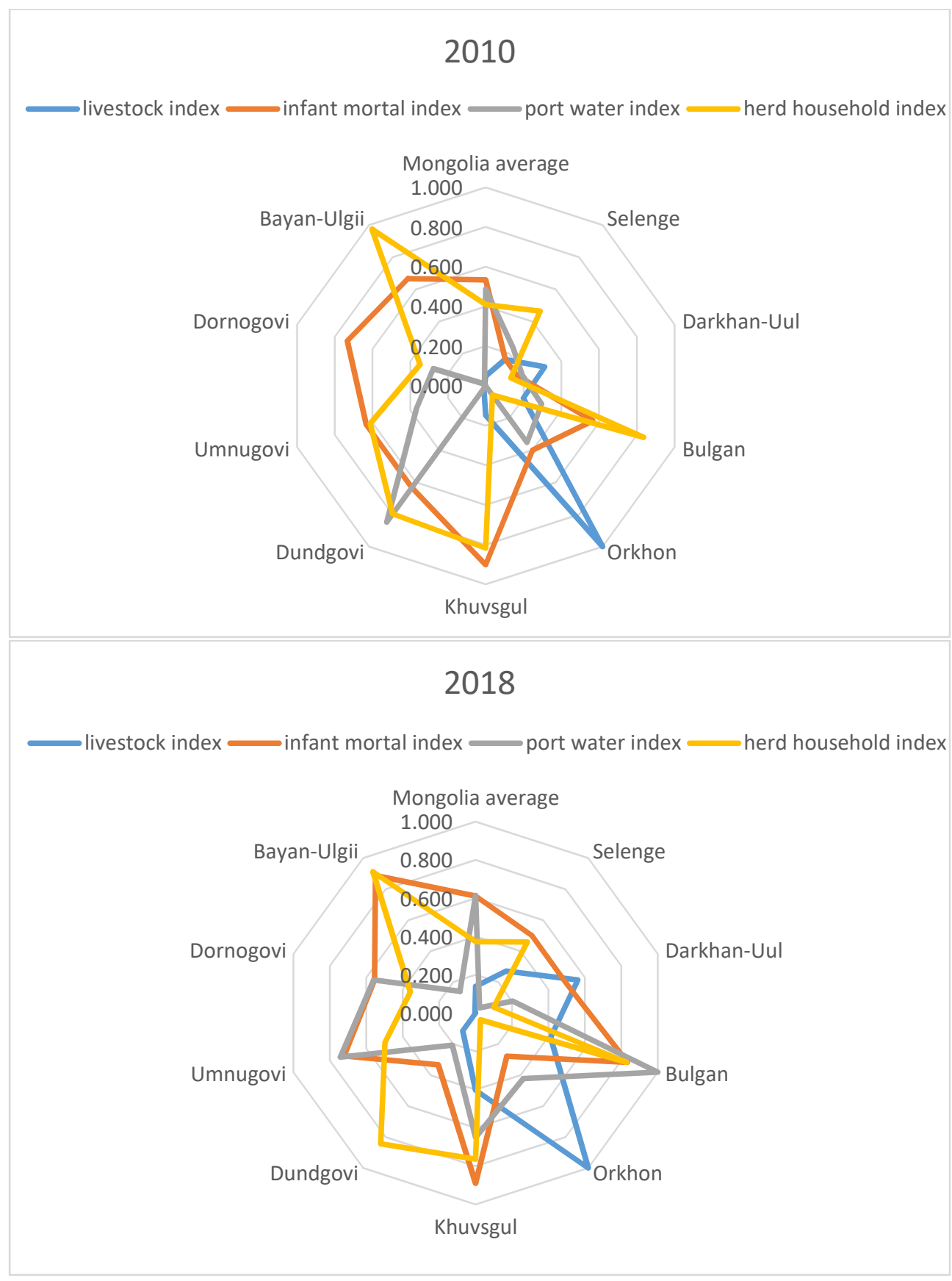

Fig. 4. Livestock, infant mortality, portable water and herder households indices. 
G. Jordan et al. studied the Bulgan River watershed in Western Mongolia where water scarcity is an increasing threat. In other parts of Mongolia, a rise in water demand as a result of mining activities, intensification of agriculture production, increasing sedentarism and urbanization following socio-economic change and rapid economic expansion has already been documented. In recent years water scarcity problems are aggravated by raising ambient temperatures resulting in rising evapotranspiration and an overall increase in precipitation variability, which together lead to decreasing water availability. [11] We tried to reflect it with portable water index, based on share of households using portable water supply in general households' number. In 2010 only Dundgovi aimag exceeded average line, but in 2018 we see a growing number of households using portable water supply in Bulgan, Khuvsgul, Umnugovi and Dornogovi aimags, probably due to internal migration flows to these aimags. It can be confirmed or disproved using field studies in situ since such information is not available in statistics.

Until the early 1990s, Mongolia's rangelands were sustainably grazed by domestic livestock for centuries, under several different governance regimes [12], and livestock populations remained relatively constant for most of the 20th century. Following the transition to a democracy and market economy, and privatization of formerly state-owned livestock in 1992, the livestock population increased steeply until 1999. The national herd declined $30 \%$ between 1999 and 2002 due to drought combined with extremely cold winters, but recovered to its previous peak by 2009, when another harsh winter killed 8.5 million livestock, about $20 \%$ of the national herd [13]. Following this second crash, the national herd again quickly recovered. From 1992 to 2013 herd composition also shifted, with an increasing proportion of goats to meet the rising global demand for cashmere. [14]

Orkhon aimag ranks №1 by the livestock index, that shows the distribution of aimags on livestock density. In 2010 there was 174.1 heads per sq. km, while the average country level was only 36.2 heads per sq. $\mathrm{km}$. And that was density based on the entire territory, but if to count livestock density based on pasture area, then pattern looks even worse - almost 427 heads per sq. km with country average of 29 heads. Such an extremely high livestock density in the smallest aimag negatively affected the quality of pasture land. After 8 years Orkhon is a leader still, but the value has decreased to 290.2 heads per sq. km. In common, the pasture load has increased significantly from 29.4 to 60.2 heads per sq. km, in 2010 there were only 3 areas with livestock density more than 100 heads per sq. km (Orkhon, Darkhan-Uul and Ulaanbaatar), then in 2018 already 7 aimags have this density and 4 aimags with density from $90-100$ heads per sq. $\mathrm{km}$.

Desertification processes have a great impact on the living standard of herders and during last 8 years the share of herders' households in total number of households has a trend to reduce slightly. A significant increase in the nomadic population began with the privatization of agricultural enterprises and livestock as a result of the reforms of the 1990s. Nomadic population increased 2.9 times since 1990 (147.5 thous. people) till 2000 (421.4 thous. people), then slightly decreased to 327.2 thous. people (2010) and 288.7 thous. people (2018). Among the aimags in question Bayan-Ulgii, Bulgan, Khuvsgul and Dundgovi have a share of herder households more than $50 \%$.

Despite the herders number decrease last years, the number of livestock does not decrease, but continues to increase (from $32.7 \mathrm{mln}$ heads in 2010 to $66.5 \mathrm{mln}$ heads in 2018), and the density of livestock grows too. In addition, as in the whole country, the structure of the herd changed, the share of goats increased from $19.8 \%$ in 1990 to $40.8 \%$ in 2018 due to the high market demand for goat wool - cashmere. Goats are considered to have the most negative impact on the pastures, since they trample down pasture stronger than other livestock and eat almost all vegetation, after that restoration of pasture vegetation is difficult enough. 
As we can see at fig. 5 the most part of aimags demonstrate the close shares of goat in herd about $30-40 \%$, but in Umnugovi aimag the share of goats was $45.2 \%$ in 1990 and by 2018 has grown to $65.1 \%$. And if to take into account aimag's arid climate conditions, high pasture load, quite high increased goat share, increased portable water and infant mortality indices and developing mining industry we think that Umnugovi aimag needs to be considered in more details.

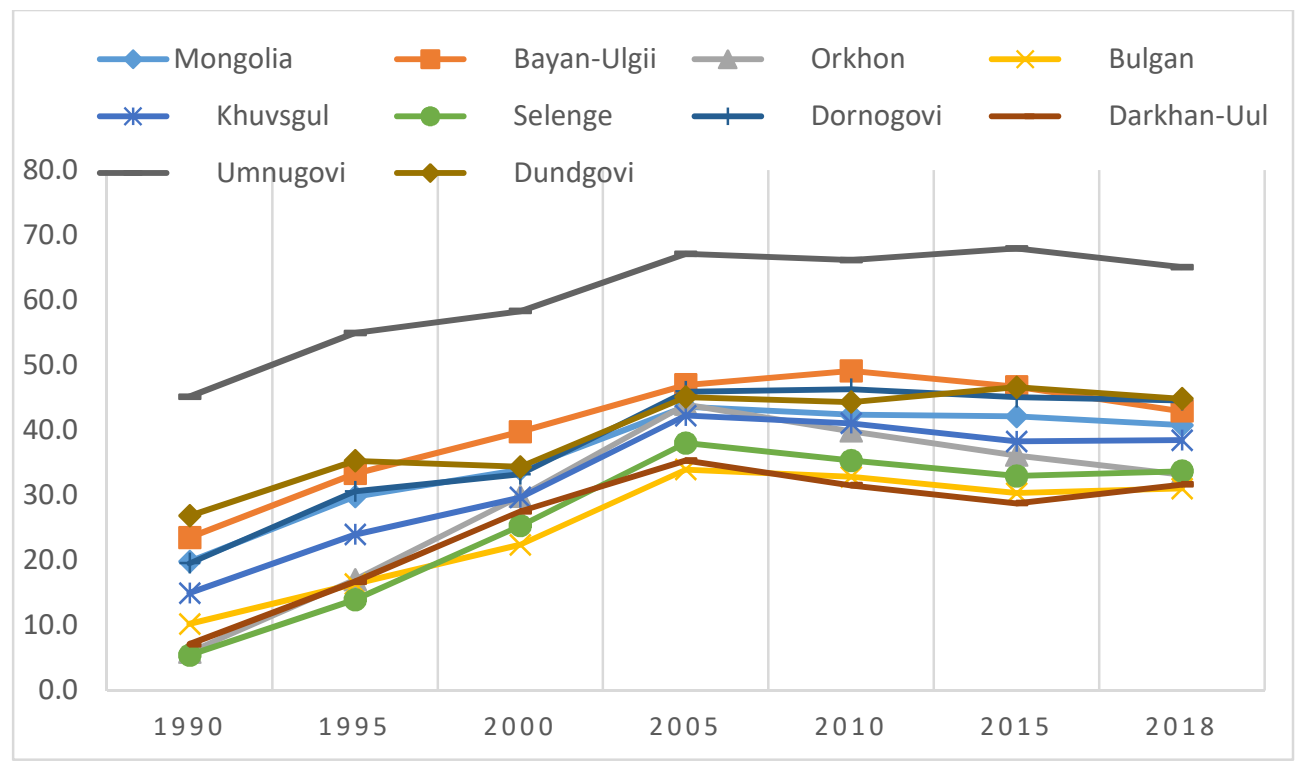

Fig. 5. Goats share dynamics.

\section{Conclusion}

The primary task of Mongolia resettlement system improving is to support the balanced combination of large cities growth with development of aimag centers and small towns in rural areas. The substantial growth of Ulaanbaatar and other large cities was provided by the rural population migration, especially young people, that affected on livestock breeding labour forces. The urbanization process in Mongolia is associated not only with economic growth or changes in the economy structure. There is a significant correlation between urbanization and natural processes, such as drought and heavy snowfall, which negatively affect livestock production. Rural people prefer to migrate to cities and go into trade and other informal side jobs, as well as have access to better education and healthcare services.

In general, the current situation requires the land use mechanisms improving and necessitates the raft of measures aimed at reducing of anthropogenic pressure and socioeconomic consequences of desertification in Mongolia.

At present time Mongolia has a wide range of livestock development programs aimed at creating a competitive and cost-effective market environment, providing the population with healthy and safe food, providing the consumer market with high-quality raw materials and increasing export of products. The main national programs are "Mongolian Animal Husbandry", which has been implemented since 2010 (stage I - 2010-2015, II- 20162020), "Animal Health", and "Cashmere Program". Along with that there are some international projects:

- The "Green Gold" project (2017-2020), backed by the Swiss Agency for Development and Cooperation and implemented nationwide by the Mongolian Association 
of Pastureland User Groups. The project is among the most influential of several aiming to improve rangeland conditions through cooperative groups of herders. Project goal: to contribute to improving livelihoods through sustainable pasture management, good marketing, politics and the legal environment with a budget of $9.73 \mathrm{mln}$ swiss francs. [15]

- The project on "Market and Pastures Management" sponsored by the International Fund for Agriculture Development for 2017-2021. Project goal: to invest in the implementation of joint programs in agriculture and the Mongolian Animal Husbandry and improve the livelihood of poor citizens and pastoralists in aimag and soum centers with budget of $\$ 9.1 \mathrm{mln}$ in credit form.

- The project "Improving livelihoods through cooperative growth" for 2018-2022 with budget $\$ 3 \mathrm{mln}$

- The project "Additional financing for the agricultural and rural development" for 2016-2020 with budget of $\$ 50 \mathrm{mln}$ in credit form sponsored by Asian Development Bank. [16]

Thus, our further interest is the study of the effectiveness of these programs and projects, an assessment of its impact on the life of pastoralists in conjunction with the dynamics of desertification processes. To draw up a complete and detailed pattern of the herders' living standard, it is necessary to conduct the field surveys and sociological polls at model territories.

The study was carried out under the state assignment of the Baikal institute of nature management $S B R A S$.

\section{References}

1. Review of programme planning and implementation (Item 5(e) of the provisional agenda) Desertification and Land Degradation in North-East Asia NEASPEC/SOM(21)/5 UN ESCAP 16-17 March 2017, Seoul, Republic of Korea

2. Combating Desertification in North-East Asia NEASPEC WORKING PAPER November 2012

3. Z. Batjargal, 1997. Desertification in Mongolia. Rangeland Desertification International Workshop, 16-19 September. Reykjavik, Iceland

4. Desertification database https://eic.mn/DLDbase/ in Mongolian

5. Munkhtsetseg Garchinbyamba \& Hoduck Kang, Forest Science and Technology 9:2 (2013) 59-64

6. T. Sternberg, Journal of Arid Environments 72 (2008) 1294-1304

7. Mongolian Statistical Information Service http://1212.mn/

8. B. Oyungerel Special protected natural territories. Ulaanbaatar: Edmon, 2004. -320 p. in Mongolian

9. D.A. Darbalaeva Urbanization and desertification processes interrelation: the aimag Orkhon of Mongolia case study Proc. Int. Conf. Science and Technology for Desertification Control, Beijing, 2014

10. T. Chuluun Land Degradation and Desertification in Mongolia [Electronic resource] / T. Chuluun, M. Altanbagana, B. Tserenchunt. - URL: http://www.undp.mn/nhdr2011/Background \%20paper/NHDR \%202011_Background $\% 20$ paper \%20draft \%202_T.Chuluun_Desertification_Eng.pdf

11. G. Jordan et al., Agriculture, Ecosystems and Environment 251 (2018) 180-193

12. M. Fernandez-Gimenez, Geographical Review 89 (3), (1999) 315-342 
13. ReliefWeb, 2010. Mongolia: Severe Winter - Dzud (Jun 2010). Edited by U. N. Office for the Coordination of Humanitarian Affairs

14. J. Khishigbayar et al., Journal of Arid Environments 115 (2015) 100-112

15. N. Purevdorj Mongolian nomads create shared funds and financial security. December 24, 2019. http://greenmongolia.mn/?p=36994\&lang=en

16. Ministry of Food, Agriculture and Light Industry http://mofa.gov.mn/exp/blog/15/31\# in Mongolian 